\title{
COMPUTER MODELING AS THE MAIN STAGE OF ENDODONTIC ROOT NEEDLE REFINEMENT
}

KAZAKOVA LARISA N., ORCID ID: 0000-0001-8060-1348; C. Med. Sci., associate prodessor of the Department of pediatric dentistry and orthodontics of Saratov State Medical University n.a. V.I. Razumovsky, Russia, 410012, Saratov,

B. Kazachya str., 112

TERESHCHUK OKSANA S., ORCID ID: 0000-0002-4917-797X; assistant of professor of the Department of emergency, anesthesiology, resuscitation and simulation technologies in medicine of Saratov State Medical University n.a. V.I. Razumovsky, Russia, 410012, Saratov, B. Kazachya str., 112, e-mail: kleo.ok@yandex.ru NEBOGATIKOV ROMAN S., 1st year Master program student of Saratov State Technical University named after Y. Gagarin, Russia, Saratov, Polytechnicheskaya str., 77, e-mail: nebogatikov.r.@gmail.com KULIGIN ALEXANDER V., ORCID ID: 0000-0001-5705-215X; D. Med. Sci., professor, the Head of the Department of emergency, anesthesiology, resuscitation and simulation technologies of medicine of Saratov State Medical University n.a.V.I. Razumovsky, Russia, 410012, Saratov, B. Kazachya str., 112, e-mail: avkuligin@yandex.ru SUETENKOV DMITRIY E., C. Med. Sci., associate professor, the Head of the Department of pediatric dentistry and orthodontics of Saratov State Medical University n.a. V.I. Razumovsky, Russia, 410012, Saratov, B. Kazachya str., 112, tel. 8-937-966-70-72, e-mail: suetenkov@gmail.com

PICHKHIDZE SERGEY YA., D. Tech. Sci., professor of the Department of materials science and biomedical engineering of Saratov State Technical University named after Y. Gagarin, Russia, Saratov, Polytechnicheskaya str., 77, e-mail: serg5761@yandex.ru

\begin{abstract}
The issue of high-quality root canal treatment in deciduous and permanent teeth is currently highly relevant. There is a huge variety of tools, devices, and medicines that can be used for working with the root canals. It is often the case that in the dental market medical products of various quality characteristics are being offered for a certain manipulation, leaving consumers face to face with a tough choice of what to buy to obtain good results. According to the English-language literature review, evaluation of the technical characteristics of endodontic needles and the results of their use in practice showed a rather large number of negative aspects, which outlines the need to find the ways of endodontic needle refinement. Aim. This study aims to determine the optimal technical characteristics of endodontic root needles and to develop a new design of the endodontic needle to be applied for the uniform irrigation of the root canal delta with a minimum probability of damaging periapical tissues. Material and methods. Solid Works software package was selected as the primary working tool because it allows to build a 3D model of biological and technical models and offers the possibility to choose the material from the existing library or to create one's own material. For the accuracy and clarity of the calculations, a biological model of the tooth and two needle models (a prototype and a modernized design) were built. Results and discussion. The result of the study is a new model of the endodontic root needle, which assures uniform irrigation of the entire surface of the root canal with minimal probability of damage to periodontal tissues. The technical solution was achieved by imparting to the design all the advantages of the analogues whilst eliminating their disadvantages. Conclusion. The technical solution proposed in our work is the new model of the endodontic needle, which enables uniform irrigation along the entire perimeter of the root canal surface and minimizes the likelihood of damaging periapical tissues even when the needle is inserted into the root canal at a maximum depth. Key words: root canal, periapical tissues, endodontic needle, drug treatment.

For reference: Kazakova LN, Tereshchuk OS, Nebogatikov RS, Kuligin AV, Suetenkov DE, Pichkhidze SYa. Computer modeling as the main stage of endodontic root needle refinement. The Bulletin of Contemporary Clinical Medicine. 2021; 14 (1): 76-82. DOI: 10.20969/VSKM.2021.14(1).76-82.
\end{abstract}

\section{КОМПЬЮТЕРНОЕ МОДЕЛИРОВАНИЕ - ОСНОВНОЙ ЭТАП УСОВЕРШЕНСТВОВАНИЯ ЭНДОДОНТИЧЕСКИХ КОРНЕВЫХ ИГЛ}

КАЗАКОВА ЛАРИСА НИКОЛАЕВНА, ORCID ID: 0000-0001-8060-1348; канд. мед. наук, доцент кафедры стоматологии детского возраста и ортодонтии ФГБОУ ВО «Саратовский государственный медицинский университет им. В.И. Разумовского» Минздрава России, Россия, 410012, Саратов, ул. Б. Казачья, 112, e-mail: avkuligin@yandex.ru TEPEЩУК ОКСАHA CEPIEEBHA, ORCID ID: 0000-0002-4917-797X; ассистент кафедры неотложной анестезиологореанимационной помощи и симуляционных технологий в медицине ФГБОУ ВО «Саратовский государственный медицинский университет им. В.И. Разумовского» Минздрава России, Россия, 410012, Саратов, ул. Б. Казачья, 112, e-mail:kleo.ok@yandex.ru

НЕБОГАТИКОВ РОМАН СЕРГЕЕВИЧ, студент I курса магистратуры Саратовского государственного технического университета им. Ю.А. Гагарина, Россия, Саратов, ул. Политехническая, 77, e-mail: nebogatikov.r.@gmail.com КУЛИГИН АЛЕКСАНДР ВАЛЕРЬЕВИЧ, ОRCID ID: 0000-0001-5705-215X; ДокТ. меД. наук, професСор, зав. кафедрой неотложной, анестезиолого-реанимационной помощи и симуляционных технологий в медицине ФГБОУ ВО «Саратовский государственный медицинский университет им. В.И. Разумовского» Минздрава России, Россия, 410012, Саратов, ул. Б. Казачья, 112, e-mail: avkuligin@yandex.ru 
СУЕТЕНКОВ ДМИТРИЙ ЕВГЕНЬЕВИЧ, канД. МеД. наук, ДоценТ, зав. кафедрой стоматологиИ Детского возраста и ортодонтии ФГБОУ ВО “Саратовский государственный медицинский университет им. В.И. Разумовского» Минздрава России, Россия, 420012, Саратов, ул. Б. Казачья, 112, e-mail: suetenkov@gmail.com

ПИЧХИДЗЕ СЕРГЕЙ ЯКОВЛЕВИЧ, докт. ТеХн. наук, профессор кафедры материаловедения и биомедицинской инженерии Саратовского государственного технического университета им. Ю.А. Гагарина, Россия, Саратов, ул. Политехническая, 77, e-mail: serg5761@yandex.ru

Реферат. До сегодняшнего дня остается актуальным вопрос качественной обработки корневых каналов в молочных и постоянных зубах. Для работы в корневых каналах предлагается огромный выбор различных инструментов, аппаратов, медикаментов. Часто на стоматологическом рынке для проведения одной и той же манипуляции предлагаются различные по качественным характеристикам изделия медицинского назначения, и потребители стоят перед выбором, что приобрести для получения хорошего результата. Оценка технических характеристик эндодонтических игл и результатов их использования в практике при анализе англоязычной литературы показала достаточно большое количество отрицательных сторон, что определяет необходимость поиска пути усовершенствования эндодонтической иглы. Цель исследования - определить оптимальные технические характеристики эндодонтических корневых игл и разработать новую конструкцию эндодонтической иглы, обеспечивающей равномерное орошение дельты корневого канала с минимальной вероятностью повреждения периапикальных тканей. Материал и методы. Программный пакет Solid Works был выбран в качестве основного рабочего инструмента, поскольку он позволяет построить трехмерную модель биологических и технических моделей и дает возможность выбрать материал из существующей библиотеки или создать собственный материал. Для точности и наглядности расчетов были построены биологическая модель зуба и две модели иглы (прототип и модернизированная конструкция). Результаты и их обсуждение. Результатом исследования стала новая модель эндодонтической корневой иглы, обеспечивающей равномерное орошение всей поверхности корневого канала с минимальной вероятностью повреждения тканей пародонта. Техническое решение достигнуто за счет передачи конструкции всех достоинств аналогов при устранении их недостатков. Выводы. Техническим результатом нашей работы стала новая модель эндодонтической иглы, которая обеспечивает равномерное орошение по всему периметру поверхности корневого канала с минимизацией вероятности повреждения периапикальных тканей даже при максимальной глубине введения иглы в корневой канал.

Ключевые слова: корневой канал, периапикальные ткани, эндодонтическая игла, медикаментозная обработка. Для ссылки: Компьютерное моделирование - основной этап усовершенствования эндодонтических корневых игл / О.С. Терещук, Р.С. Небогатиков., А.В. Кулигин [и др.] // Вестник современной клинической медицины. 2021. - Т. 14, вып. 1. - С.76-82. DOI: 10.20969/VSKM.2021.14(1).76-82.

ntroduction. The questions of how to treat, with

what to treat, and how to re-treat root canals have not lost their relevance to this day, despite the creation of modern equipment, new materials, and existence of written protocols for root canal treatment [1].

The main reason for this is the complex anatomy of the root canals, the morphological and histological features of the tissues which form this organ - all this creates a number of difficulties inthe endodontic treatment. The effectiveness of the treatment of pulpitis and periodontitis is directly dependent on the sequence of actions during the root canal treatment.

The first step is to carefully remove all infected tissue from the root canal lumen under the antiseptic bath, avoiding, if possible, pushing the contents behind the apex. The second step is to mechanically remove the infected tissue from the walls of the root canal using endodontic instruments, upon the removal of which part of the chip remains on the root canal walls and lumen. The next stage is the drug treatment, with which the root canal delta is cleaned of chips, microorganisms, and the smeared layer [1-4].

For a long time, the most common way of delivering an antiseptic to the root canal during drug treatment was to use a narrow gauze swab on a rigid base the root needles. Gauze swabs were administered repeatedly and the choice of antiseptic depended on the diagnosis. Nowadays, another method for the delivery of antiseptics has gained popularity:delivery via the endodontic root needles. It allows introducing a significant amount of antiseptic into the root canal in a short period of time. The range of needles available on the market is diverse, each needle has its own parameters, they differ in length, diameter, appearance, and the material of which they are made. Knowledge of the methodology and acorrectly justified choice of the instrument for the treatment of complicated caries affect the treatment's outcome $[1,5]$.

The relevance of research. The literature review showed that there are two groups of endodontic needles for manual irrigation: open-ended and closed-ended needles. In the first group - the tip of the needle ends with a hole, in the second group - it is blindly closed, with the needle opening on the sides. Open-ended endodontic needles can end with a flat, beveled, or notched apical end, while closed-ended endodontic needles can be side-vented, double side-vented and multi-vented $[5,6]$. Figure 1 shows the different needles designs and their models used in the study by Boutsioukis (2010) evaluating irrigant flow in the root canal [6].

Open-ended needles, unlike closed-ended ones, better wash the apical part of the root canal, but their use leads to a rather high risk of injection of the solution into the periapical tissues due to a strong increase in pressure, whereas the blind needles have inversely proportional properties. A beveled needle is the most dangerous of its type because of the risk of injury and jamming [7]. Later on, it was proposed to improve multivented needles by creating a protrusion of $0,03 \mathrm{~mm}$ height or a $0,04 \mathrm{~mm}$ deep dimple on their blind tip to control the flow [8]. There are different opinions on the effectiveness of the needles used: Boutsioukis et al. in their studies on irrigation did not find any differences in 
A
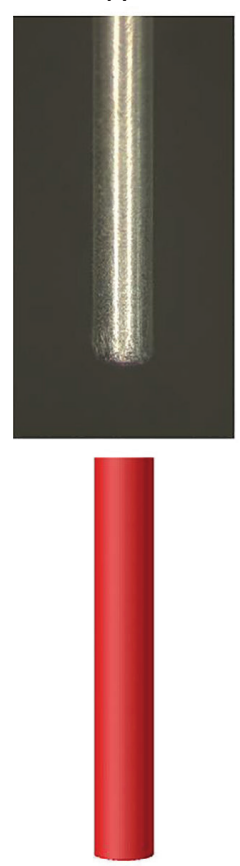

B

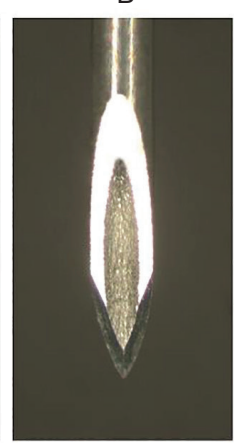

1
C
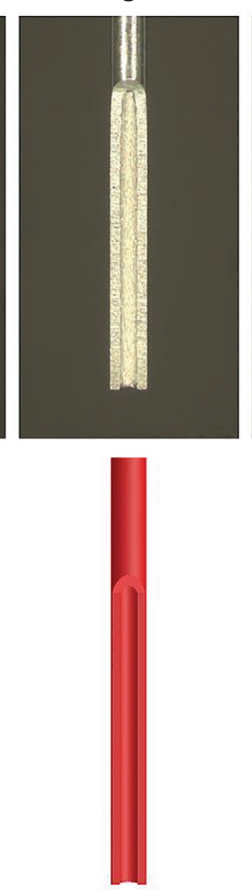

D
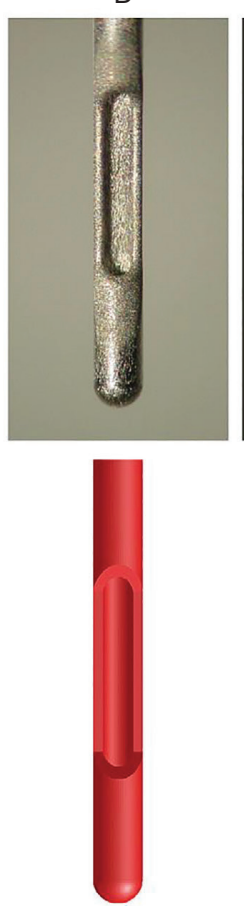

E
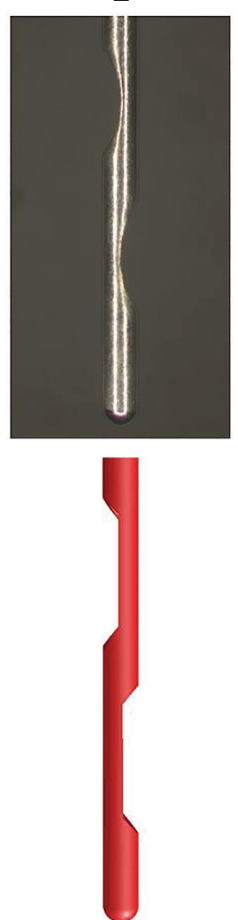

$\mathrm{F}$
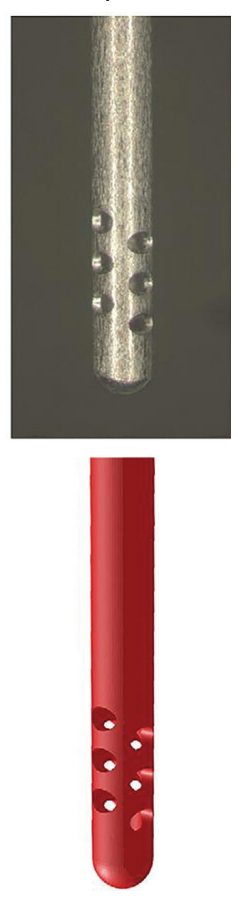

Figure 1. Different needle designs for root canal irrigation: A - flat; B - beveled; C - notched; D - side-vented; $\mathrm{E}$ - double side-vented; F - multi-vented

the effectiveness of side-vented and double side-vented needles [9].

Khan et al., studying comparatively the operation of needles in the root canals, reported that side-vented needles were more effective than ordinary ones [7, $10,11]$. High-quality drug treatment of the root canal depends on many factors, with a lot of attention paid by the researchers to the depth of insertion of the endodontic needle. Emel Uzunoglu-Özyürek, like most researchers, considered 2 levels of insertion: $1 \mathrm{~mm}$ less than the working length and $3 \mathrm{~mm}[7,12]$. An analysis of their results shows that open-ended needles can be inserted by $3 \mathrm{~mm}$ less than the working length, while closed-ended ones - by $1 \mathrm{~mm}$ less than the working length to increase the efficiency of treating the apical third.

Of equal importance is the determination of the adequate pressure for the creation of the optimal flow rate during irrigation of the root canal walls and for the active replacement of the antiseptic solution volume with a new volume, without damaging the periapical tissues [13]. Excessively high pressure can lead to the damage of periodontal tissues not only by the "air bubble», formed near the apical foramen due to the surface tension of the solution, but also by the subsequent removal of the irrigant itself. The root canal irrigation is based on Pascal's law, according to which the pressure equals the force divided by the surface area; the value is not scalar. According to Boutsioukis research, many factors influence the force exerted by doctors for creating optimal pressure, including: the gender of the doctor, work experience, type of canal, material from which the syringe is made, diameter of the needle, needle type. Therefore, one cannot speak of any exact universal value of pressure created in the cylinder of the syringe. Most often, it is considered to be in the range of $400-550 \mathrm{kPa}$. As a result, the irrigant flow rate is also different [5]. A solution flow rate of $>0,1 \mathrm{~m} / \mathrm{s}$ was taken as desired for the optimal tissue irrigation and solution exchange in the canal. The rate of the flow coming out of the holes in the needles decreases 5-10 times, which affects the depth of the solution exchange from the tip of the needle. The flow itself can mechanically clean the walls of the root canals of a large area under the pressure from the perforations of the needles or simply from the filling of the canal with the irrigant. Studies have shown a higher degree of cleaning from a direct hit of the flow onto the canal walls under pressure than from a simple filling $[13,14]$.

In addition to the speed, the direction of flow created by using endodontic needles of various groups also affects the depth of exchange. For open-ended needles, the flow is directed towards the apex of the root, and for closed-ended ones - towards the side of the walls. The lateral flow direction allows a well mechanical cleaning of the walls, while the apical direction provides for a better exchange of the solution at a depth [10, 12]. In terms of the depth of exchange, flat, beveled, and notched endodontic needles showed the best performance, delivering a «new» solution to a depth of $2,5 \mathrm{~mm}$ from the tip of the needle, while side-vented and double side-vented needles showed a worse result - up to $1,5 \mathrm{~mm}$, and multi-vented needle - up to $1 \mathrm{~mm}$. Based on these data, it becomes clear that openended needles deliver the irrigant well to the depth, but increase the risk of damage to periapical tissues. Therefore, in order to prevent damage, it is better to use a multi-vented needle $[10,12]$. 
In their study, Boutsioukis noted that the pressure created by the flow of open-ended needles in the apical third of the canal of size 30 and $2 \%$ taper was on average about $400 \mathrm{kPa}$, while of closed-ended needles - about $120 \mathrm{kPa}$. These values confirm the danger of using open type needles [5, 6, 14].

O'Connel noted that manual irrigation leads to satisfactory irrigation of the upper and middle parts of the root canal, but not enough of the apical third. This is due to the surface tension of the solution, which allows for the formation of an «air bubble» $[6,14]$.

The detailed analysis of different types of irrigation needles reveals their significant disadvantages, which seriously affect the irrigation exchange in various parts of root canals. Even if all requirements on injection depth and piston pressure are observed it is not possible to control the rate of antiseptic flow in the root canal and, therefore, to guarantee an effective and safe method of solutions' delivery.

Research Goal. This study aims to determine the optimal technical characteristics of endodontic root needles and to develop a new design of the endodontic needle which will provide for the uniform irrigation of the root canal delta with a minimum probability of damaging periapical tissues.

Data and Methods. Solid Works software package was selected as the main working tool because it allows to build a 3D model of biological and technical models and offers the possibility to choose the material from the existing library or to create one's own material.

For the accuracy and clarity of the calculations, a biological model of the tooth and two needle models (a prototype and a modernized design) were built. The analysis of the effectiveness of irrigation of the root delta of the tooth and the likelihood of damage to the periapical tissues was carried out in the Solid Works Flow Simulation software supplement package.

Results and Discussion. The result of the study is a new model of the endodontic root needle, which provides uniform irrigation of the entire surface of the root canal, with minimal probability of damage to periodontal tissues [15].

The technical solution was achieved by imparting to the design all the advantages of the analogues, whilst eliminating their disadvantages. The design of the endodontic needle contains holes: 1 hole on the tip of the needle and 168 holes staggered on the side surface of the needle. All holes have the same diameter of $0,1 \mathrm{~mm}$, which helps equalize the pressure and reduce the speed of the central stream to the speed of the peripheral flows. This ensures uniform irrigation and minimizes the likelihood of damage to the alveolar bone.

The 3D model of the newly developed endodontic needle model is illustrated on Figure 2. The main function of the endodontic root needle is to deliver an antiseptic to the root canal in a certain volume and to process it well without damaging the periodontal tissue. Considering all the possible parameters during the antiseptic treatment - the rate of insertion, the depth of insertion of the endodontic needle into the root canal, the volume of the antiseptic, the shape and volume of the root canal, - we analyzed the results of modeling of the biological tooth model with a new needle. The obtained results are shown on Figure 2 and in Table.

The calculations were carried out at the insertion of the needle at $1 / 3,2 / 3$ and $3 / 3$ of the depth of the root canal, with a pressure on the liquid of $50 \mathrm{~Pa}$. To compare the results, identical calculations were carried out with the well-known model with the introduction of a needle $1 / 3$ of the length of the root canal.

Figure 3 presents the results of the analysis of the effectiveness of root canal irrigation using various needle models and their positions.

In Figure 3, the displayed models show the following: a) a study of dentin irrigation using a known needle model; b) an enlarged image of the apex in the study of dentin irrigation; c) a study of irrigation of dentin using the newly developed needle immersed by $1 / 3$; d) an enlarged image of the apex in the study of dentin irrigation; e) a study of irrigation of dentin using the newly developed needle immersed by $2 / 3$; f) an enlarged image of the apex in the study of dentin irrigation; g) research of dentin irrigation using the newly developed needle immersed by $3 / 3$; h) an enlarged image of the apex in the study of dentin irrigation. Table.

The generalized results of the study are given in

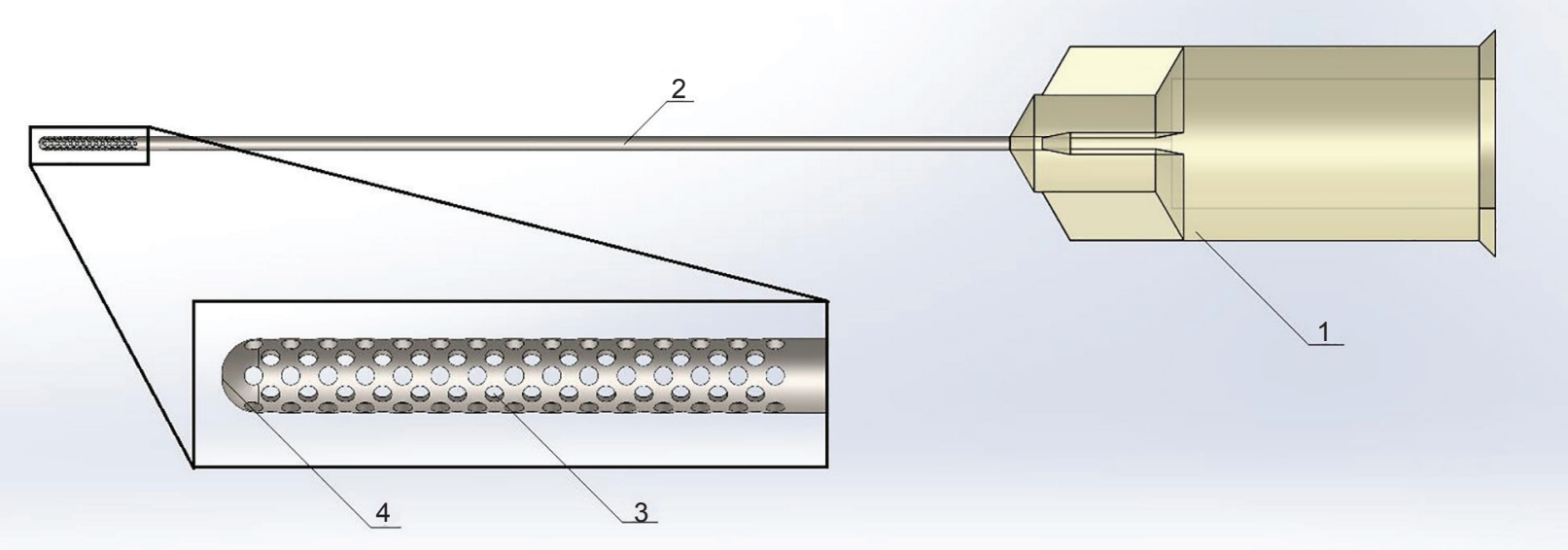

Figure 2. Modernized endodontic needle: 1 - cannula; 2 - the body of the needle; 3 - side holes; 4 - hole on the tip 

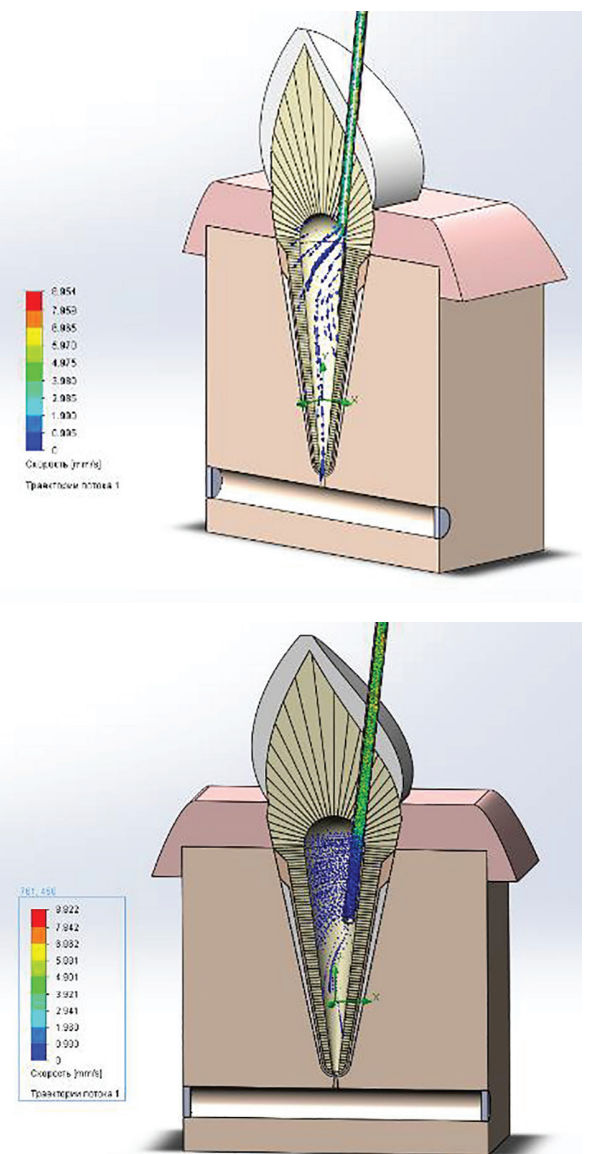

C

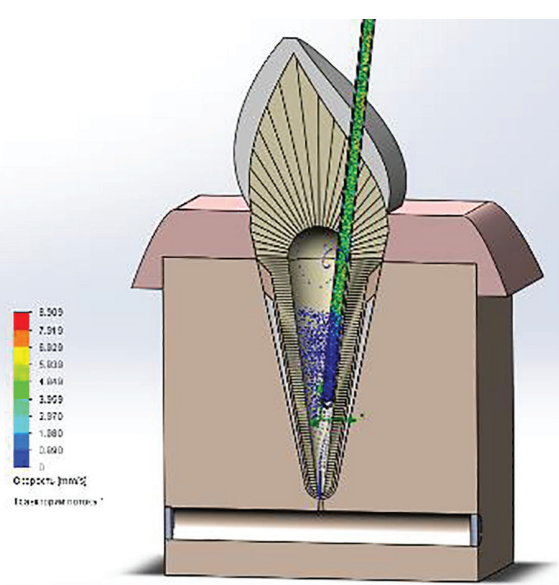

e

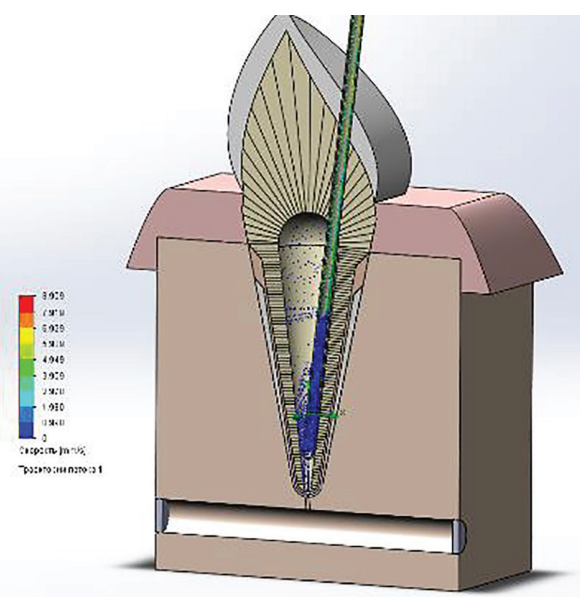

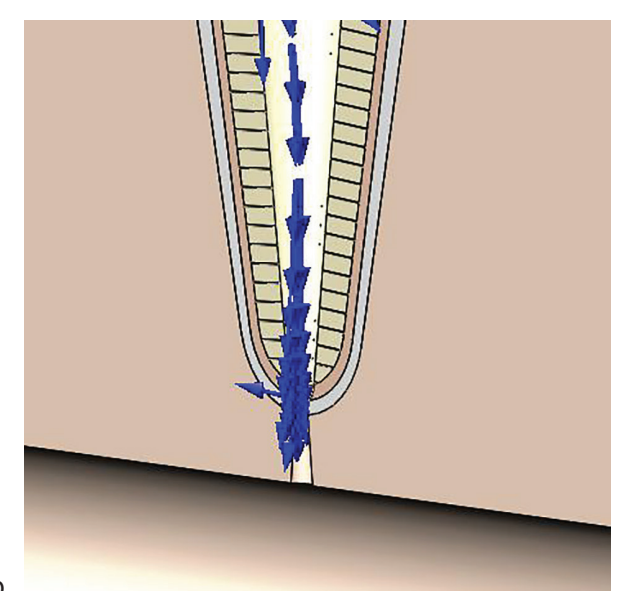
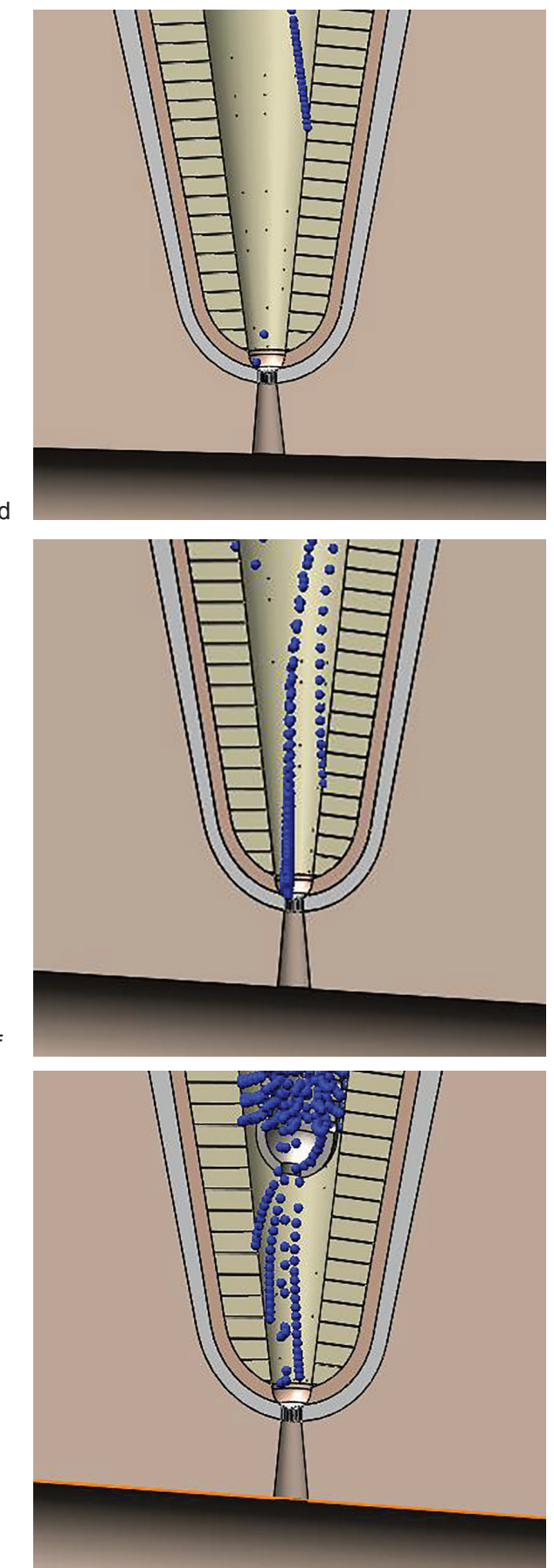

Figure 3. Comparison of the hydrodynamic characteristics of a known and a modernized needle design 
The results of the analysis of effectiveness

of the well-known and the modernized needle models

\begin{tabular}{|l|c|c|}
\hline \multicolumn{1}{|c|}{ Parameter } & Well-known model & Uodernized model \\
\hline Linear flow rate in the needle & $7-8$ & $6-7$ \\
\hline Linear flow rate in the root canal & $5-6$ & $3-4$ \\
\hline $\begin{array}{l}\text { Irrigation angle of the irrigant (including all } \\
\text { needle openings) }\end{array}$ & $45-60$ & 360 \\
\hline Condition of periapical tissues & Damaged & Nogrees damaged \\
\hline
\end{tabular}

Analysis of the data in Table demonstrates the benefits of the newly developed design of endodontic needle.

Conclusion. The technical solution as a result of our work is a new model of the endodontic needle, which provides uniform irrigation along the entire perimeter of the surface of the root canal while minimizing the likelihood of damage to periapical tissues even with a maximum depth of insertion of the needle into the root canal.

Transparency of the study. The study did not have sponsorship. The authors are solely responsible for the provision of the final version of the manuscript for publication.

Declaration of financial or other relationships. All authors participated in the conception and design of the study and in the writing of the manuscript. The final version of the manuscript was approved by all the authors. The authors did not receive a fee for the study.

\section{ЛИТЕРАТУРА}

1. Оценка эфффективности применения различных протоколов удаления смазанного слоя на этапе финишной ирригации / К.А. Лаптева, Д.С. Шабалина, Д.В. Киселева, И.А. Готтман / Вестник Уральской медицинской академической науки. - 2018. - Т. 15, №. 5. - С.77-84.

2. Болячин, А.В. Ирригация системы корневого канала: современные принципы и методики / А.В. Болячин, Т.А. Беляева // ДентАрт. - 2010. - № 1. - С.19-22.

3. Болячин, А.В. Основные принципы и методики ирригации системы корневого канала в эндодонтии: Ч. 1, 2 / А.В. Болячин // Клиническая эндодонтия. - 2008. № 1/2. - C.45-51.

4. Гатина, Э.Н. Современные возможности ирригации корневых каналов / Э.Н. Гатина, Г.Р. Егорова, Ю.В. Фазылова // Молодой ученый. - 2015. - № 11. - С.631-635.

5. Measurement of pressure and flow rates during irrigation of a root canal ex vivo with three endodontic needles / C. Boutsioukis, T. Lambrianidis, E. Kastrinakis, P. Bekiaroglou // International Endodontic Journal. 2007. - № 4. - C.504-513.

6. The effect of root canal taper on the irrigant flow: evaluation using an unsteady Computational Fluid Dynamics model / C. Gogos, B. Verhaagen, M. Versluis [et al.] // International Endodontic Journal. - 2010. - T. 43. - C.909-916.

7. Karpagam, G. Nithya.Types of needles used in the irrigation of root canal system - (a review) / G. Karpagam, J.D. Raj // Drug Invention Today. - 2018. - Vol. 10, special issue 3. - P.234-237.

8. Numerical investigation of root canal irrigation adopting innovative needles with dimple and protrusion / Li Ping, Zhang Di, Xie Yonghui, Lan Jibing// Acta of Bioengineering and Biomechanics. - 2013. - Vol. 15. - P.124-128.

9. Scanning electron microscopy analysis of rins Endo system and conventional irrigation for debris removal /
R.R. Vivan, M.V. Bortolo, M.A. Duarte [et al.] // Brazilian Dental Journal. - 2010. - Vol. 21. - P.305-309.

10. Efficacy of Four Irrigation Needles in Cleaning the Apical Third of Root Canals / J.M. Guerreiro-Tanomaru, L.L. Etchebehere, M.R. Dornelles [et al.] // Brazilian Dental Journal. - 2013. - Vol. 24 (1). - P.21-24.

11. Three-dimensional numeric simulation of root canal irrigant flow with different irrigation needles / Y. Shen, Y. Gao, W. Qian [et al.] // International Endodontic Journal. 2010. - № 36. -P.884-901.

12. Karaaslan, $H$. Uzunoglu-Özyürek Emel.Influence of size and insertion depth of irrigation needle on debris extrusion and sealer penetration/ H. Karaaslan, S.A. Türker, Ö. Bahar // Restorative Dentistry and Endodontics. 2018. - Vol. 43 (1), № 2. -P.125-129.

13. Effect of Canal Anastomosis on Periapical Fluid Pressure Build-up during Needle Irrigation in Single Roots with Double Canals using a Polycarbonate Mode / Q. Huang, J.B. Barnes, G.J. Schoeffe [et al.] // Scientific Reports. 2017. - Vol. 7. - P.1582-1584.

14. Intra-canal Pressure Produced by Three Irrigation System: A Comparative Study / L.A. Shalan, H.F. Alhuwaizi, A.A. Fatalla, A.S. Hameed // Journal of Research in Medical and Dental Science. - 2018. - Vol. 6, № 5. P.161-164.

15. Патент на полезную модель № 195903 «Эндодонтическая игла для проведения антисептической обработки корневого канала» / Л.Н. Казакова, О.С. Терещук, Р.С. Небогатиков, С.Я. Пичхидзе.

\section{REFERENCES}

1. Sorokoumova DV, Lapteva KA, Shabalina DS, Kiseleva DV, Gottman IA. Ocenka effektivnosti primeneniya razlichnyh protokolov udaleniya smazannogo sloya na etape finishnoj irrigacii kornevogo kanala [Evaluation of the effectiveness of applying various protocols for removing the smeared layer at the stage of final irrigation of the root canal] Vestnik Ural'skoy medicinskoy akademicheskoy nauki [Bulletin of the Ural Medical Academic Science]. 2018; 15 (5): 77-84.

2. Bolyachin AV, Belyaeva TA. Irrigaciya sistemy kornevogo kanala: sovremennye principy i metodiki [Irrigation of the root canal system: modern principles and techniques]. DentArt [DentArt]. 2010; 1: 19-22.

3. Bolyachin AV. Osnovnye principy i metodiki irrigacii sistemy kornevogo kanala v endodontii. CHast' 1 i 2 [Basic principles and methods of irrigation of the root canal system in endodontics. Part 1 and 2] Klinicheskaya endodontiya [Clinical endodontics]. 2008; 1-2: 45-51.

4. Gatina EN, Egorova GR, Fazylova YuV. Sovremennye vozmozhnosti irrigacii kornevyh kanalov [Modern possibilities of root canal irrigation]. Molodoy Uchenyii [Young scientist]. 2015; 11: 631-635.

5. Boutsioukis C, Lambrianidis T, Kastrinakis E, Bekiaroglou $P$. Measurement of pressure and flow rates during irrigation of a root canal ex vivo with three endodontic needles. International Endodontic Journal. 2007; 40: 504-513. 
6. Boutsioukis C, Gogos C, Verhaagen B, Versluis M, Kastrinakis E, van der Sluis LWM. The effect of root canal taper on the irrigant flow: evaluation using an unsteady Computational Fluid Dynamics model. International Endodontic Journal. 2010; 43: 909-916.

7. Karpagam G Nithya, Raj James David. Types of needles used in the irrigation of root canal system - A review. Drug Invention Today. 2018; 10 (3): 234-237.

8. Li Ping, Zhang Di, Xie Yonghui, Lan Jibing. Numerical investigation of root canal irrigation adopting innovative needles with dimple and protrusion. Acta of Bioengineering and Biomechanics. 2013; 15 (1): 124-128.

9. Vivan RR, Bortolo MV, Duarte MA, Moraes IG, Tanomaru Filho M, Bramante CM. Scanning electron microscopy analysis of rins endo system and conventional irrigation for debris removal. Brazilian Dental Journal. 2010; 21 : 305-309.

10. Guerreiro-Tanomaru Juliane Maria, Loiola Lívia Etchebehere, Morgenta Renata Dornelles, Leonardo Renato de Toledo, Tanomaru-Filho Mario. Efficacy of Four Irrigation Needles in Cleaning the Apical Third of Root Canals. Brazilian Dental Journal. 2013; 24 (1): 21-24.

11. Shen Y, Gao Y, Qian W, Ruse ND, Zhou X, Wu H. Threedimensional numeric simulation of root canal irrigant flow with different irrigation needles. International Endodontic Journal. 2010; 36: 884-901.

12. Uzunoglu-Özyürek Emel, Karaaslan Hakan, Türker Sevinç Aktemur, Bahar Özçelik. Influence of size and insertion depth of irrigation needle on debris extrusion and sealer penetration. Restorative Dentistry and Endodontics. 2018; 43 (1), 2: 125-129.

13. Huang Qi, Barnes Jonathan B., Schoeffe G John, Fan Bing, Tay Candice, Bergeron Brian E, Susin Lisiane F, Junqi Ling, Lina Niu, Franklin RTay. Effect of Canal Anastomosis on Periapical Fluid Pressure Build-up during Needle Irrigation in Single Roots with Double Canals using a Polycarbonate Model. Scientific Reports. 2017; 7: 1582.

14. Shalan Linz A, Alhuwaizi Hussain F, Fatalla Abdalbseet Ahmad, Hameed Ammar Saleem. Intra-canal Pressure Produced by Three Irrigation System: A Comparative Study. Journal of Research in Medical and Dental Science. 2018; 6 (5): 161-164.

15. Kazakova LN, Tereshchuk OS, Nebogatikov RS, Kuligin AV, Suetenkov DYe, Pichkhidze SYa. Patent na poleznyu model' № 195903 Endodonticheskaya igla dlya provedeniya antisepticheskoj obrabotki kornevogo kanala [Utility Model Patent № 195903 «Endodontic needle for antiseptic root canal treatment»]. 